\title{
POLA ASUH PENGETAHUAN PEMBERIAN MAKAN DENGAN STATUS GIZI BALITA
}

\author{
Indra Domili ${ }^{凶}$, Zulfiah Nurhidayah Tangio, Fitri Yani Arbie, M. Anas Anasiru, \\ Rahma Labatjo, Novian Swasono Hadi \\ Jurusan Gizi Poltekkes Kemenkes Gorontalo
}

\section{ARTICLE INFO \\ Article history}

Submitted : 2021-04-05

Revised : 2021-10-19

Accepted : 2021-11-24

\section{Keywords:}

Stunting

Mothers' knowledge

Feeding practice

Nutritional status

\section{Kata Kunci:}

Stunting

Pengetahuan Ibu

Pemberian Makan

Status Gizi

\begin{abstract}
Stunting is a nutritional problem that can reduce the quality of life of children later. There are several factors associated with stunting, including maternal knowledge. This study aims to determine the relationship between the knowledge of child feeding parenting styles and stunting incidence in Ilotidea Village, Tilango District, Gorontalo District. The research method used a cross-sectional study. The nutritional status was obtained by measuring the height/length of the toddler's body using a microtoise and measuring body length. Meanwhile, the age can be obtained through birth certificates or family cards. The two data were then categorized by using the index of height or body length according to age using the WHO Antro 2005 classification. Data regarding knowledge of feeding parenting styles for toddlers was obtained using a questionnaire. Statistical analy sis used the chi-square test with a significance level of 0.05 and $95 \%$ CI. A sample of 33 toddlers was taken using random sampling. The results showed that the knowledge of child feeding parenting affects the incidence of stunting ( $\mathrm{p}$-value $=$ 0.006). Conclusions about the knowledge of child feeding contribute to feeding practice. Therefore, efforts are needed to increase access to information regarding proper feeding for toddlers.

Stunting sebagai masalah gizi yang dapat menurunkan kualitas hidup anak nantinya. Terdapat beberapa faktor yang berhubungan dengan stunting, termasuk pengetahuan ibu. Penelitian ini bertujuan untuk mengetahui hubungan pengetahuan pola asuh pemberian makan pada balita dengan kejadian stunting di Desa Ilotidea Kecamatan Tilango Kabupaten Gorontalo. Metode penelitian menggunakan cross sectional study. Data mengenai status gizi balita didapatkan dengan pengukuran tinggi/panjang badan balita dengan menggunakan microtoise dan alat ukur panjang badan. Data mengenai umur balita didapatkan melalui akta kelahiran ataupun kartu keluarga. Kedua data kemudian dikategorikan dengan menggunakan indeks tinggi badan atau panjang badan menurut umur dengan menggunakan klasifikasi WHO Antro 2005. Data mengenai pengetahuan pola asuh pemberian makan pada balita didapatkan dengan menggunakan kuesioner. Analisis statistik menggunakan uji chi-square dengan taraf signifikansi 0,05 dan CI 95\%. Sampel sebanyak 33 balita y ang diambil menggunakan random sampling. Hasil Penelitian yaitu pengetahuan pola asuh pemberian makan pada balita berpengaruh terhadap kejadian stunting ( $\mathrm{p}$-value $=0,006)$. Kesimpulan pengetahuan mengenai pemberian makan pada balita berkontribusi terhadap praktik pemberian makan. Oleh karenanya, diperlukan usaha peningkatan akses informasi mengenai pemberian makan y ang tep at pada balita.
\end{abstract}

$\triangle$ Corresponding Author:

Indra Domili

Jurusan Gizi Poltekkes Kemenkes Gorontalo

Telp. 085256869346

Email: indra.domili76@gmail.com

\section{PENDAHULUAN}

Pendek atau stunting (short stature) dengan indikator tinggi badan atau panjang badan menurut umur (TB-PB/U) digunakan sebagai indikator gizi salah kronik yang menggambarkan riwayat gizi kurang anak dalam jangka waktu lama. Definisi pendek dan sangat pendek adalah status gizi yang didasarkan pada indeks Panjang Badan menurut Umur (PB/U) atau Tinggi Badan menurut Umur $(\mathrm{TB} / \mathrm{U})$ yang merupakan istilah stunting (pendek) dan severely stunted. Batasan lain tentang stunting (tubuh pendek) adalah keadaan tubuh yang sangat pendek hingga melampaui defisit 2 SD di bawah median panjang atau tinggi badan populasi yang menjadi referensi 
internasional. Stunting berhubungan erat dengan ketersediaan bahan pangan yang rendah yang artinya dapat berpengaruh langsung terhadap asupan makan balita sehari-hari, penyakit infeksi yang berulang dan pola asuh orang tua terhadap balita (Wiyono, 2016).

Kejadian stunting dapat disebabkan beberapa faktor seperti balita yang tidak mendapatkan air susu ibu (ASI) eksklusif dengan alasan ASI yang sulit keluar saat pertama bayi lahir sehingga diberikan susu formula. Hal ini termasuk dalam kelompok pola asuh tentang pemberian makanan pada balita. Tingkat pengetahuan gizi ibu dapat mempengaruhi kejadian stunting karena hal tersebut termasuk kelompok pola asuh tentang kepekaan makan pada balita. Adapun faktor lainnya pendapatan orang tua, pendidikan ibu dapat mempengaruhi kejadian stunting terhadap balita karena kurang asupan makanan zat gizi yang cukup (Nìmah Khoirun \& Nadhiroh, 2015).

Pola asuh pemberian makanan oleh orang tua mempengaruhi status gizi balita. Semakin baik pola asuh yang diberikan orang tua semakin baik pula status gizi balita begitupun sebaliknya jika pola asuh orang tua kurang baik dalam pemberian makanan maka status gizi balita akan terganggu. Sebaiknya petugas kesehatan memberikan penyuluhan kepada orang tua yang memiliki balita agar orang tua lebih mengetahui kepekaan melakukan pola asi, asah, asuh yang baik dan benar agar dapat menunjang perkembangan dan pertumbuhan anak dengan baik. Hal ini perlu kepekaan pemantauan dalam pemberian gizi secara intensif sehingga angka kejadian gangguan gizi atau kejadian stunting dapat dioptimalkan (Munawaroh, 2015)'(Anasiru \& Domili, 2017).

Riset Kesehatan Dasar tahun 2018 mencatat prevalensi pendek dan sangat pendek pada balita sebesar 30,8\%. Provinsi Gorontalo mempunyai angka prevalensi stunting yang lebih tinggi dari angka nasional, yaitu 32,5\% (Badan Penelitian dan Pengembangan Kesehatan, 2019). Tingginya angka prevalensi stunting ini memerlukan upaya pencegahan dan penanganan. Salah satunya melalui pengembangan riset yang berbasis stunting. Penelitian ini fokus pada pola asuh yang spesifik menyangkut pengetahuan mengenai tata cara pemberian makan pada kelompok umur balita, yang kemudian akan dilihat korelasinya dengan kejadian stunting. Tujuan dari penelitian ini adalah untuk menginvestigasi hubungan antara pengetahuan ibu mengenai pola asuh pemberian makan terhadap kejadian stunting pada balita.

\section{METODE PENELITIAN \\ Jenis Penelitian}

Jenis penelitian adalah penelitian survey analitik dengan pendekatan cross sectional study.

\section{Jenis Variabel}

Variabel dalam penelitian ini terbagi atas variabel bebas dan terikat. Variabel bebas yaitu pola asuh. Sedangkan variabel terikat yaitu status gizi balita.

\section{Lokasi dan Waktu Penelitian}

Penelitian dilakukan di Desa Ilotidea Kecamatan Tilango Kabupaten Gorontalo. Penelitian dilaksanakan pada Bulan April - Mei 2020.

\section{Populasi dan Sampel}

Populasi penelitian adalah seluruh balita yang ada di Desa Ilotidea Kecamatan Tilango Kabupaten Gorontalo. Sampel berjumlah 33 balita yang ditentukan dengan metode simple random sampling.

\section{Pengumpulan Data}

Data mengenai status gizi balita didapatkan dengan pengukuran tinggi/panjang badan balita dengan menggunakan microtoise dan alat ukur panjang badan. Selanjutnya data mengenai umur balita didapatkan melalui akta kelahiran ataupun kartu keluarga. Kedua data kemudian dikategorikan dengan menggunakan indeks tinggi badan atau panjang badan menurut umur dengan menggunakan klasifikasi WHO Antro 2005.

Data mengenai pengetahuan pola asuh pemberian makan pada balita didapatkan dengan menggunakan kuesioner. Kuesioner berisi pertanyaan mengenai jenis dan frekuensi makan yang sesuai untuk balita dan teknik pemberian makan yang sesuai. Selanjutnya data tersebut dikategorikan menjadi dua kategori, yaitu baik dan kurang.

\section{Pengolahan dan Analisis Data}

Analisis data menggunakan uji chi square. Uji statistik untuk menilai ada tidaknya hubungan 
antara varibel status gizi dengan pengetahuan ibu mengenai pola asuh pemberian makan pada balita. Nilai Confidence Interval (CI) sebesar $95 \%$.

\section{HASIL PENELITIAN \\ Karakteristik Sampel}

Karakteristik sampel yang diamati mencakup sebaran umur, jenis kelamin dan status gizi tinggi/panjang badan menurut umur. Data mengenai karakteristik sampel disajikan pada tabel 1.

Tabel 1. Karakte ristik Sampel

\begin{tabular}{clcc}
\hline Karateristik & Kategori & $\begin{array}{c}\text { Frekuensi } \\
(\mathrm{n})\end{array}$ & $\begin{array}{c}\text { Persentasi } \\
(\%)\end{array}$ \\
\hline \multirow{2}{*}{ Umur } & $0-23$ & 8 & 24,24 \\
(bulan) & $24-35$ & 10 & 30,30 \\
Jenis & $36-59$ & 15 & 45,46 \\
Kelamin & Laki-laki & 14 & 42,42 \\
& Perempuan & 19 & 57,58 \\
\multirow{2}{*}{ Status Gizi } & Stunting & 19 & 57,58 \\
& Tidak & 14 & 42,42 \\
\hline
\end{tabular}

\section{Jenis dan Frekuensi Makan}

Jenis makanan yang dimaksud dalam penelitian ini adalah komposisi makanan yang diberikan pada balita. Komposisi makanan yang ideal yaitu berupa makanan pokok, lauk, sayur dan buah. Sedangkan frekuensi makan mencakup kerap kali makan yang terdiri dari tiga kali makan dan dua kali selingan.

Berdasarkan data hasil penelitian, dari 22 orang responden yang memiliki pengetahuan kurang, sebanyak 15 orang responden memberikan makanan kepada balita dengan komposisi menu hanya terdiri dari makanan pokok dan lauk. Sedangkan 7 orang responden memberikan komposisi menu berupa makanan pokok, lauk, dan sesekali diberikan sayur ataupun buah.

Sebanyak 22 orang responden yang berpengetahuan kurang, 17 orang responden memberikan makan sebanyak 3 kali sehari tanpa makanan selingan. Tiga orang responden memberikan makan tiga kali makanan pokok dan sekali makanan selingan. Sedangkan 2 orang responden memberikan dua kali makanan pokok dan 2 kali makanan selingan.

\section{Waktu Pemberian Makan}

Waktu pemberian makan yang dimaksud dalam penelitian ini adalah ketepatan waktu pemberian makan sesuai dengan jadwal sarapan, makan siang, makan malam dan selingan. Sebagian besar responden (12 orang) dengan pengetahuan kurang, tidak memberi makan anaknya sesuai dengan jadwal pemberian makan. Mereka sering tidak memberikan makan tepat waktu.

Waktu makan yang sering dilewati adalah makan pagi. Seringkali, makan pagi diberikan pada siang hari. Sedangkan di pagi hari, balita hanya diberikan minuman teh manis.

\section{Teknik Pemberian Makan}

Teknik pemberian makan adalah keahlian ibu ataupun pengasuh dalam memberi makan balita. Keahlian pemberian makan mencakup pengetahuan mengenai porsi makan yang cukup sesuai dengan umur balita, cara pengolahan, makanan alternatif jika balita tidak menyukai jenis makanan tertentu, adanya pujian ataupun bujukan untuk meningkatkan nafsu makan anak.

Sebanyak 16 orang responden yang berpengetahuan kurang tidak memberikan porsi makan sesuai umur balita. Mereka memberikan makanan orang dewasa ataupun makanan keluarga tanpa memperhitungkan adanya perbedaan kecukupan kebutuhan zat gizi bagi balita. Sehingga, kebutuhan nutrisi balita tidak tercapai.

Teknik pengolahan makanan untuk balita telah diterapkan dengan baik oleh seluruh responden. Bagi balita yang belum sempurna pertumbuhan gigi geliginya, teknik pengolahan makanan diutamakan dengan tekstur lunak. Begitupun untuk balita yang sudah bisa mengunyah dengan baik, tekstur makanan sudah seperti makanan keluarga pada umumnya.

Sehubungan dengan keahlian responden dalam meningkatkan nafsu makan balita, sebagian besar responden (19 orang) tidak mengetahui jenis makanan alternatif ataupun modifikasi menu bagi balita yang sulit makan. Merekapun cenderung tidak memberikan motivasi seperti bujukan dan pujian bagi balita. Oleh karenanya, balita sering merasa bosan dan tidak berselera makan.

\section{Pola Asuh Pengetahuan Pemberian Makan dan Status Gizi Balita}

Variabel pola asuh yang menjadi fokus penelitian ini adalah pengetahuan ibu mengenai 
pemberian makan pada balita. Data mengenai variabel-variabel tersebut disajikan dalam tabel 2. Berikut.

Tabel 2. Pengetahuan Pola Asuh Pemberian Makan dan Status Gizi Balita

\begin{tabular}{lcccc}
\hline $\begin{array}{l}\text { Status Gizi } \\
(\text { TB/U) }\end{array}$ & \multicolumn{2}{c}{ Pengetahuan } & Jumlah & $\begin{array}{c}p \text { - } \\
\text { value }\end{array}$ \\
\cline { 2 - 3 } & Baik & Kurang & & 17 \\
\hline Stunting & 2 & 15 & & \\
Tidak stunting & 9 & 7 & 16 & 0,006 \\
Total & 11 & 22 & 33 & \\
\hline
\end{tabular}

Hasil uji chi-square dengan CI 95\% menunjukkan bahwa pengetahuan ibu mengenai pola asuh pemberian makan pada balita berhubungan dengan kejadian stunting. Pola asuh menjadi salah satu faktor yang berhubungan erat dengan status gizi, khususnya kejadian stunting pada balita (Aridiyah, Rohmawati, \& Ririanty, 2015).

Pengetahuan mengenai pemberian makan pada balita pada penelitian ini mencakup pengetahuan mengenai jenis dan frekuensi makan, waktu pemberian makanan pendamping ASI (MP-ASI), dan teknik pemberian makan. Pengetahuan mengenai asupan gizi seimbang pada masa balita, terbukti secara signifikan berhubungan dengan status gizi balita (Susanti, 2018).

\section{PEMBAHASAN}

Umur

Tiap tahapan di usia balita berkontribusi terhadap tumbuh kembang dan status kesehatan. Pada tahapan baduta (12-23 bulan) merupakan tahapan kritis di mana paling sering terjadi masalah kesehatan, seperti penyakit infeksi yang dapat mempengaruhi status gizi (Welasasih \& Wirjatmadi, 2012). Pada masa ini terjadi perubahan asupan jenis makanan yang signifikan, yaitu dari makanan semi padat ke makanan padat. Anak di usia ini sudah bisa memilih makanan yang disukai, sehingga seringkali anak menolak jenis makanan tertentu. Akibatnya asupan gizi dapat berkurang. Dalam jangka panjang, kekurangan gizi kronis akan berakibat pada gagal tumbuh, seperti stunting.

Namun, hasil yang berbeda ditunjukkan oleh penelitian yang dilakukan oleh Habimana dan Biracyaza (2019), yang menyatakan bahwa anak pada kelompok umur 24 - 59 bulan memiliki resiko untuk menderita stunting dua kali lebih tinggi dibandingkan dengan kelompok umur di bawahnya (Habimana \& Biracyaza, 2019). Anak pada kelompok umur 24-59 bulan telah lebih mandiri dibandingkan dengan anak yang berada di kelompok umur di bawahnya. Anak pada rentang umur tersebut sudah mulai bersosialisasi dengan teman sebaya. Sehingga, pengaruh teman sebaya akan berkontribusi juga terhadap asupan makan balita. Pengaruh teman sebaya terhadap kebiasaan makan anak bersifat negatif. Pengaruh negatif tersebut terutama pada konsumsi makanan tinggi kalori dan bernutrisi rendah. Anak akan lebih terpengaruh untuk mengkonsumsi jenis makanan yang tinggi kalori dan bergizi jika teman sebaya dan saudaranya mengkonsumsi jenis makanan tersebut(Habimana \& Biracyaza, 2019).

\section{Jenis Kelamin}

Hasil penelitian ini menunjukkan bahwa stunting paling banyak diderita oleh anak perempuan. Namun, hal berbeda ditunjukkan oleh penelitian lainnya yang menyatakan bahwa anak laki-laki memiliki resiko menderita stunting sebanyak 1,08 kali dibandingkan dengan anak perempuan. Demikian pula halnya dengan kasus stunting lebih banyak ditemui pada anak laki-laki dibandingkan dengan perempuan (Habimana \& Biracyaza, 2019; Islam et al., 2018).

Jenis kelamin tidak berpengaruh signifikan terhadap status gizi balita, khususnya tinggi badan. Beberapa penelitian menitikberatkan pada jumlah kasus stunting pada kelompok jenis kelamin tertentu, namun dengan hasil analisis hubungan yang menyatakan tidak adanya hubungan antara kedua variabel tersebut (Hasanah, 2018),(Dewi \& Adhi, 2016).

Dengan demikian, dapat dikatakan bahwa hubungan antara jenis kelamin dengan kejadian stunting belum dapat dijelaskan dengan pasti. Secara biologis, pada kelompok umur balita, belum terjadi perbedaan pertumbuhan, khususnya tinggi badan yang signifikan antara laki-laki dan perempuan. Perbedaan tinggi badan akan jelas terlihat pada saat anak berumur di atas enam tahun, yaitu pada saat mencapai titik growth spurt.

\section{Status Gizi}

Menurut klasifikasi status gizi dengan menggunakan indeks tinggi/panjang badan 
menurut umur, sebagian besar sampel termasuk dalam kategori stunting. Hasil ini menunjukkan bahwa stunting masih menjadi masalah gizi di Provinsi Gorontalo dengan prevalensi yang tinggi. Hal inipun sejalan dengan laporan Riskesdas pada tahun 2018, yang menyatakan bahwa angka pervalensi stunting di Provinsi Gorontalo berada di atas angka nasional (Badan Penelitian dan Pengembangan Kesehatan, 2019).

Anak yang menderita stunting beresiko untuk mengalami masalah kesehatan dan penurunan daya kognitif, sehingga pada saat dewasa akan menurunkan tingkat produktivitas dan kualitas hidup. Resiko yang dapat disebabkan oleh stunting, yaitu peningkatan resiko angka kesakitan dan kematian, abnormalitas sistem reproduksi, dan peningkatan resiko obsesitas serta penyakit penyerta (Dewey \& Begum, 2011; World Health Organization, 2013). Selain itu, anak stunting cenderung akan menderita penyakit degeneratif pada saat dewasa (World Health Organization, n.d.).

\section{Jenis dan Frekuensi Makan}

Terkait dengan pengetahuan mengenai jenis dan frekuensi makan pada balita, sebagian besar ibu balita stunting memberikan makanan selingan kurang dari 2 kali sehari. Pemberian makanan dengan frekuensi minim dapat meningkatkan resiko stunting sebanyak 20,1\% (Udoh \& Amodu, 2016).

Selain itu pula, ibu balita stunting tidak memberikan jenis makanan yang beragam. Mereka juga tidak mengetahui makanan kesukaan anak. Oleh karenanya, nafsu makan balita menurun dan asupannya pun berkurang.

Keragaman jenis makanan yang diberikan pada balita yang disarankan adalah minimal 4 kelompok pangan (makanan pokok, lauk, sayur dan buah) (Menteri Kesehatan Republik Indonesia, 2014). Tujuan pemberian makanan yang beragam adalah untuk memenuhi kebutuhan zat gizi baik makro maupun mikro. Selain itu pula untuk mencegah kebosanan pada balita.

Pada kelompok umur 0-23 bulan, keragaman makanan berkorelasi dengan kejadian stunting (Ahmad, Khalique, Khalil, Urfi, \& Maroof, 2018; Fekadu, Mesfin, Haile, \& Stoecker, 2015; Kim, Mejía-Guevara, Corsi, Aguayo, \& Subramanian, 2017; Rakotomanana, Gates, Hildebrand, \& Stoecker, 2017; Tiwari,
Ausman, \& Agho, 2014; Udoh \& Amodu, 2016) Semakin beragam makanan yang diberikan, maka akan menurunkan resiko stunting pada anak. Anak yang mengkonsumsi jenis makanan dari lebih dari 4 kelompok pangan, cenderung terhindar dari masalah pertumbuhan, seperti stunting(Damanik \& Wanda, 2019).

Sesuai rekomendasi oleh WHO, komposisi makanan balita minimal terdiri dari makanan pokok dengan satu jenis protein hewani dan satu jenis sayur atau buah(Udoh \& Amodu, 2016). Hasil penelitian menunjukkan bahwa balita stunting memiliki komposisi makan yang hanya terdiri dari dua kelompok pangan, yaitu makanan pokok dan lauk hewani. Minimnya kelompok pangan yang dikonsumsi menyebabkan tidak tercukupinya asupan zat gizi lainnya, seperti vitamin, mineral dan serat. Sehingga, dalam jangka waktu yang lama, berkonsekuensi negatif terhadap pertumbuhan anak.

\section{Waktu Pemberian MP-ASI}

Sebagian besar ibu yang mempunyai balita stunting tidak mengetahui mengenai pentingnya waktu pemberian MP-ASI yang tepat. Mereka umumnya mengetahui waktu pemberian MP-ASI, yaitu pada saat anak berusia 6 bulan. Namun, untuk alasan mengapa harus diberikan pada saat anak berumur 6 bulan, para ibu tidak bisa menjawab dengan tepat. Mereka cenderung memilih untuk memberikan MP-ASI tidak sesuai dengan rekomendasi yang telah mereka ketahui.

Waktu pemberian MP-ASI yang tepat dapat mencegah terjadinya masalah gizi. WHO merekomendasikan pemberian MP-ASI setelah anak berusia lebih dari 6 bulan (World Health Organization, 2017). Rekomendasi oleh European Society for Pediatric Gastroenterology, Hepatology and Nutrition (ESPGHAN) menyebutkan bahwa pemberian MP-ASI dilakukan pada saat anak berumur lebih dari 17 minggu dan tidak lebih dari 26 minggu (Agostoni et al., 2008).

Pemberian MP-ASI yang tidak tepat dapat menyebabkan meningkatnya resiko stunting sebanyak tiga kali(Aguayo, Badgaiyan, \& Paintal, 2015). MP-ASI direkomendasikan untuk diberikan setelah periode ASI eksklusif. Hal tersebut berkaitan dengan kesiapan sistem pencernaan anak. Pencernaan anak siap untuk makanan padat setelah berumur 6 bulan. 
MP-ASI yang diberikan terlalu dini akan berakibat fatal bagi pencernaan dan pertumbuhan anak. Hal ini disebabkan karena sistem pencernaan yang belum siap untuk memproses makanan semi-padat dan makanan padat. Oleh karenanya, anak yang diberikan MP-ASI terlalu dini akan beresiko menderita diare dan infeksi saluran pernapasan atas(Beka Sariy, Yosephin Simanjuntak, \& Suryani, 2018).

Pemberian MP-ASI yang sesuai dapat menunjang asupan gizi anak yang sudah tidak bisa dicukupi lagi oleh ASI. Sehingganya, pemberian MP-ASI yang terlambat akan meningkatkan resiko anak untuk menderita kekurangan gizi. Kondisi tersebut jika terjadi dalam jangka waktu yang lama akan meningkatkan resiko stunting. Keterlambatan waktu pemberian MP-ASI berkorelasi signifikan dengan stunting (Dhami, Ogbo, Osuagwu, Ugboma, \& Agho, 2019).

\section{Teknik Pemberian Makan}

Selain pengetahuan tentang jenis dan frekuensi makan, teknik pemberian makan pada balita juga mempengaruhi asupan makan balita. Ibu harus mengetahui mengenai waktu pemberian makan yang tepat. Selain itu pula, jika anak menolak untuk makan, ibu hendaknya bisa membujuk anak untuk makan.

Sebaliknya, jika anak dapat menghabiskan makanan yang diberikan, ibu bisa memberikan pujian pada anak. Praktek pemberian makan yang tepat dapat menunjang pertumbuhan dan perkembangan anak. Contohnya dengan menerapkan teknik melibatkan anak dalam memilih makanan serta pemberian pujian dan bujukan (Perdani, Hasan, \& Nurhasanah, 2016).

\section{KESIMPULAN DAN SARAN}

Pola asuh berkaitan dengan status gizi balita, khususnya tinggi badan. Pola asuh dapat mencakup pengetahuan ibu mengenai pemberian makan pada balita. Keahlian pemberian makan mencakup pengetahuan mengenai porsi makan yang cukup sesuai dengan umur balita, cara pengolahan, makanan alternatif jika balita tidak menyukai jenis makanan tertentu, adanya pujian ataupun bujukan untuk meningkatkan nafsu makan anak.

Oleh karenanya, untuk mencapai penurunan angka stunting, maka diperlukan upaya dalam peningkatan akses informasi mengenai pemberian makan pada balita. Akses tersebut dapat disediakan oleh petugas kesehatan melalui kegiatan penyuluhan, maupun dengan menggunakan media dengan pemanfaatan teknologi. Contohnya dengan memanfaatkan media sosial yang terbukti sangat berpengaruh terhadap paparan informasi pada masyarakat luas.

\section{DAFTAR PUSTAKA}

Agostoni, C., Decsi, T., Fewtrell, M., Goulet, O., Kolacek, S., Koletzko, B., ... Van Goudoever, J. (2008). Complementary feeding: A commentary by the ESPGHAN Committee on Nutrition. Journal of Pediatric Gastroenterology and Nutrition, 46(1), 99-110. https://doi.org/10.1097/01.mpg.00003044 64.60788.bd.

Aguayo, V. M., Badgaiyan, N., \& Paintal, K. (2015). Determinants of child stunting in the Royal Kingdom of Bhutan: an indepth analysis of nationally representative data. Maternal \& Child Nutrition, 11, 333-345. https//doi.org/ 10.1111/men. 12168 .

Ahmad, I., Khalique, N., Khalil, S., Urfi, \& Maroof, M. (2018). Dietary diversity and stunting among infants and young children: A cross-sectional study in Aligarh. Indian Journal of Community Medicine, 43(1), 34-36. https $/ /$ doi.org/ 10.4103/ijcm.IJCM_382_16.

Anasiru, M. A., \& Domili, I. (2017). Pengaruh Asupan Energi dan Protein, Pola Asuh, dan Status Kesehatan Terhadap Kejadian Stunting pada Anak usia 12-36 bulan di Puskesmas Tilango Kecamatan Tilango Kabupaten Gorontalo. Gorontalo Health Polytechnic.

Aridiyah, F. O., Rohmawati, N., \& Ririanty, M. (2015). Faktor-faktor yang Mempengaruhi Kejadian Stunting pada Anak Balita di Wilayah Pedesaan dan Perkotaan . Jurnal Pustaka Kesehatan, 3(1), 163-170. Retrieved from https://jurnal.unej.ac.id/index.php/JPK/ar ticle/view/2520/2029.

Badan Penelitian dan Pengembangan Kesehatan. (2019). Laporan Nasional RISKESDAS 2018. Retrieved from http://labmandat.litbang.depkes.go.id/ima 
ges/download/laporan/RKD/2018/Lapora

n_Nasional_RKD2018_FINAL.pdf.

Beka Sariy, R. M., Yosephin Simanjuntak, B., \& Suryani, D. (2018). Pemberian MPASI Dini dengan Status Gizi (PB/U) Usia 4-7 Bulan di Kecamatan Ratu Samban Kota Bengkulu . Jurnal AcTion, 3(2), 103-109. action.v3i2.95.

Damanik, S. M., \& Wanda, D. (2019). Pengaruh Praktik Pemberian Makan terhadap Risiko Stunting pada Balita di Beberapa Negara Berkembang: Studi Literatur. Ilmu Gizi Indonesia, 3(1), 1322. Retrieved from http//ilgi.respati. ac.id/index.php/ilgi2017/article/view/117 /pdf.

Dewey, K. G., \& Begum, K. (2011). Long-term consequences of stunting in early life. Maternal and Child Nutrition, 7(SUPPL. 3), 5-18. https://doi.org/10.1111/j.17408709.2011.00349.x.

Dewi, I. A. K. C., \& Adhi, K. T. (2016). Pengaruh Konsumsi Protein dan Seng serta Riwayat Penyakit Infeksi terhadap Kejadian Stunting pada Anak Balita Umur 24-59 Bulan di Wilayah Kerja Puskesmas Nusa Penida III. Arc. Com. Health, 3(1), 36-46. Retrieved from https://ojs.unud.ac.id/index.php/ach/articl e/view/21077/13856.

Dhami, M. V., Ogbo, F. A., Osuagwu, U. L., Ugboma, Z., \& Agho, K. E. (2019). Stunting and severe stunting among infants in India: the role of delayed introduction of complementary foods and community and household factors. Global Health Action, 12. https://doi.org/10.1080/16549716.2019.1 638020.

Fekadu, Y., Mesfin, A., Haile, D., \& Stoecker, B. J. (2015). Factors associated with nutritional status of infants and young children in Somali Region, Ethiopia: a cross-sectional study. BMC Public Health, 15(846). https//doi.org/10. 1186/s12889-015-2190-7.

Habimana, S., \& Biracyaza, E. (2019). Risk Factors Of Stunting Among Children Under 5 Years Of Age In The Eastern And Western Provinces Of Rwanda: Analysis Of Rwanda Demographic And Health Survey 2014/2015</p>. Pediatric Health, Medicine and Therapeutics,
Volume 10, 115-130. https:/doi.org/10. 2147/phmt.s222198.

Hasanah, Z. (2018). Faktor-Faktor Penyebab Kejadian Stunting pada Balita di Wilayah Kerja Puskesmas Kotagede I Yogyakarta. Yogyakarta.

Islam, M. M., Sanin, K. I., Mahfuz, M., Ahmed, A. M. S., Mondal, D., Haque, R., \& Ahmed, T. (2018). Risk factors of stunting among children living in an urban slum of Bangladesh: Findings of a prospective cohort study. BMC Public Health, 18(1), 197. https:/doi.org/10. 1186/s12889-018-5101-x.

Kim, R., Mejía-Guevara, I., Corsi, D. J., Aguayo, V. M., \& Subramanian, S. V. (2017). Relative importance of 13 correlates of child stunting in South Asia: Insights from nationally representative data from Afghanistan, Bangladesh, India, Nepal, and Pakistan. Social Science and Medicine, 187, 144-154. https://doi.org/10.1016/j.socscimed.2017. 06.017.

Menteri Kesehatan Republik Indonesia. (2014). Peraturan Menteri Kesehatan Republik Indonesia Nomor 41 tahun 2014 tentang Pedoman Gizi Seimbang. Jakarta..

Munawaroh, S. (2015). Pola Asuh Mempengaruhi Status Gizi Balita. Jurnal Keperawatan, 6(1), 44-50. Retrieved from https://ejournal.umm.ac.id/index. php/keperawatan/article/view/2851/3504.

Nìmah Khoirun, \& Nadhiroh, S. R. (2015). Faktor yang Berhubungan dengan Kejadian Stunting pada Balita. Media Gizi Indonesia, 10(1), 13-19. Retrieved from http://e-journal.unair.ac.id/index. php/MGI/article/view/3117/2264.

Perdani, Z. P., Hasan, R., \& Nurhasanah, N. (2016). Hubungan Praktik Pemberian Makan dengan Status Gizi Anak Usia 3-5 Tahun di Pos Gizi Desa Tegal Kunir Lor Mauk. JKFT, 2, 29.

Rakotomanana, H., Gates, G. E., Hildebrand, D., \& Stoecker, B. J. (2017). Situation and determinants of the infant and young child feeding (IYCF) indicators in Madagascar: Analysis of the 2009 Demographic and Health Survey. BMC Public Health, 17(1), 812. https://doi.org/10.1186/ s12889-0174835-1. 
Susanti, M. (2018). Faktor-Faktor yang Berhubungan dengan Status Gizi Balita di Kelurahan Bumijo Kecamatan Jetis Kota Yogyakarta (Politeknik Kesehatan Kemenkes Yogyakarta). Retrieved from http//eprints.poltekkesjogja.ac.id/1749/1/

MIRA SUSANTI_P07124216103 SKRIPSI.pdf.

Tiwari, R., Ausman, L. M., \& Agho, K. E. (2014). Determinants of stunting and severe stunting among under-fives: Evidence from the 2011 Nepal Demographic and Health Survey. BMC Pediatrics, 14(1), 239. https://doi.org/10. 1186/1471-2431-14-239.

Udoh, E. E., \& Amodu, O. K. (2016). Complementary feeding practices among mothers and nutritional status of infants in Akpabuyo Area, Cross River State Nigeria. SpringerPlus, 5(1), 2073. https://doi.org/10.1186/s40064-0163751-7.
Welasasih, B. D., \& Wirjatmadi, R. B. (2012). Beberapa Faktor yang Berhubungan dengan Status Gizi Balita Stunting. Public Health, 8(3), 99-104.

Wiyono, S. (2016). Epidemiologi Gizi. Jakarta: CV. Sagung Seto.

World Health Organization. (n.d.). WHO Stunting in a nutshell. Retrieved February 14, 2020, from https://www.who.int/nutrition/healthygro wthproj_stunted_videos/en/.

World Health Organization. (2013). Childhood Stunting: Context, Causes and Consequences WHO Conceptual framework.

World Health Organization. (2017). WHO | Global strategy for infant and young child feeding. In WHO. Retrieved from World Health Organization website: http://www.who.int/nutrition/publications /infantfeeding/9241562218/en/. 